\title{
EVOLUTION AND LEVEL OF AGRICULTURAL SUPPORT IN TURKEY AND IN THE EUROPEAN UNION
}

\author{
Özlem T. YILMAZ*
}

\section{Abstract}

The developments of agricultural support policies in Turkey and in the European Union are different from each other. When the EU was applying protectionist policies, Turkey was on the way of liberalising its economy in 1980s. After Uruguay Round (1995), developed countries took steps for reducing protectionist policies in agriculture for the first time. As Turkey and European Union were signatories of the Uruguay Round Agreement on Agriculture, they reduced their support levels. Despite the successful reforms and WTO (World Trade Organization) commitments, support level in the European Union remained high. Only in the last years, producer support estimate had a decreasing trend. Instead, Turkey increased the support policy that requires production and so producer support estimate increased after 2000. While the support level is not as high as in the EU, producer support estimate is at EU and OECD levels in the last years.

This paper, so as to contribute to the literature, examines the agricultural support policies and levels in Turkey and in the European Union for better understanding the differences between them. In this regard, the aim of the paper is to develop an approach to comment on the differences in agricultural policies by comparing them and on the protection levels between Turkey and European Union by using Producer Support Estimate of OECD.

Keywords: Agricultural Support Policies, Producer Support Estimate, Protection

\section{TÜRKIYY'DE VE AVRUPA BİRLIĞI'NDE TARIMSAL DESTEKLERIN GELIŞSIMI VE SEVIYESI}

\section{$\ddot{O}_{z e t}$}

Türkiye'de ve Avrupa Birliği'nde uygulanan tarım destek politikalarının gelişmeleri birbirinden çok farklıdır. 1980'li yıllarda AB korumact politikaları uygularken, Türkiye ekonomisi liberalleşme yolundaydl. Uruguay Turu (1995) sonrası, gelişmiş ülkelerde ilk kez tarımda korumacı politikaları azaltmak için adımlar atıldı. Türkiye ve Avrupa Birliği Uruguay Turu Tarım Anlaşmasını imzalayan taraflar olduğu için, destek seviyelerini zaman içinde azalttılar. Ancak

\footnotetext{
*Ph.D, e-mail: ozlemtoplu@hotmail.com
} 
başarll reformlar ve DTÖ taahhütlerine rağmen, Avrupa Birliği'ndeki destek seviyesi yüksek kaldl. Sadece son ylllarda, üretici desteği tahmininde azalan bir eğilim vardı. Bunun aksine, Türkiye üretimle bağlantılı destek seviyesini artırırken, 2000 yllından sonra üretici destek tahmini de yükselme eğilimindeydi. Türkiye'deki destek seviyesi AB'deki kadar yüksek olmasa da, üretici desteği tahmini son yıllarda $A B$ ve OECD seviyelerindedir.

Bu makale, literatüre katkı sağlamak amacıyla Türkiye ve Avrupa Birliği'ndeki tarımsal destek politikalarını ve destek seviyesini incelemektedir. Bu bağlamda, çalışmanın amacl Avrupa Birliği ve Türkiye'de uygulanan tarımsal destek politikalarının gelişimindeki ve OECD’nin Üretici Destek Eşdeğeri ölçümü yardımıyla destek seviyelerindeki farklılıkları inceleyip, yorumlamaktır.

Anahtar Kelimeler: Tarımsal Destek Politikalarl, Üretici Destek Tahmini, Korumacılık

\section{Introduction}

This article is an analysis of evolution of agricultural support policies and protection level in Turkey and in the European Union. Agricultural support policies are referred as protectionist policies. The application of these policies depends on the objective of the government; either to protect the farmers' income or to protect consumers. Also food security and sustainable farming are the other reasons of protectionist policies. Since agricultural products are mainly intended for consumption as food, which is one of humanity's basic needs, most countries try to be self-sufficient in agriculture and to provide food security to their citizens. So, each country implements an agricultural policy, whether agriculture has a great contribution to its economy or not.

This article focuses on the support policies in Turkey and in the European Union. Besides, it looks at their support levels in agriculture. Producer support estimate is one of the most widely used indicators to evaluate support level in the countries. Before passing to the evaluation of producer support estimate, a short history of the development of agricultural support policies in Turkey and in the European Union are given after this introduction part. The third chapter evaluates the agricultural support policies in two ways: Firstly, market distortions of the domestic policies are examined. Secondly, the transfers to the producers due to the support policies are measured by the OECD method (producer support estimate) to determine support level in Turkey and in the European Union. Finally, conclusion part summarizes and discusses the results. 


\section{Evolution of Agricultural Support Policies in Turkey and in the EU}

The evolution of agricultural support policies and reform process in European Union and in Turkey advanced differently. Agriculture had been a sensitive issue for most European governments even before the foundation of the European Community (EC). After World War II, agriculture constituted a key element in the European Community owing to the food shortages in the European countries. Turkey also gave importance to agriculture in the first years of foundation of Turkish Republic. State Economic Enterprises (SEEs) and Agricultural Sales Cooperative Unions (ASCUs) were established in 1930s which played key roles in implementing agricultural policies. After World War II, in 1950s, mechanization in agriculture was started with the use of tractors, and Turkey tried to catch up with the west. Until the end of 1970s Turkey pursued import-substitution-based development strategies and began to open up its economy to the world economy. In 1980s, Turkey's growth policy shifted from import-substitution to export-oriented strategy, and the priority of development was given to industrialization. After this time, the share of agriculture in national income and employment has decreased relatively. On the contrary, European Community pursued protectionist agricultural policies in 1970s and in 1980; therewith, the Community became the biggest exporter in agricultural products. As the world share of other leading exporters like USA declined, the leading exporters proposed agriculture to be included in the GATT Rounds and demanded from the Community to decrease its support level. The European Community defended the Common Agricultural Policy (CAP) because it was newly established so the Community did not want to make any commitments regarding its support policy (Ertuğrul, 2004: 11). 1990s were the years of change in the agricultural policies both in the European Union and in Turkey. One of the main catalysts of this development was the GATT Uruguay Round (1988-1994) which was the first phase of the reform towards agricultural liberalisation. In 1990, the EC realised that GATT talks could not be completed until the CAP was reformed. For the first time, EC took steps to move agricultural policy in a more liberal direction.

Besides GATT Uruguay Round Agreement, other agreements that started to shape Turkish agricultural policy after 1990s were Customs Union between Turkey and European Union which entered into force in January 1996, and stand-by agreement with IMF. The Customs Union excluded agricultural products (only processed agricultural products were included) but confirmed the possibility enclosing agriculture in time. Furthermore, with the IMF stand-by agreement (December 1999), Turkey committed to phase out production-oriented agricultural support and to replace it by income support payments.

In 2000 WTO Agriculture negotiations began under the Doha Round. The aims of the negotiations are further reforms in agriculture and more trade liberalisation. 
When the Round will be completed, the outcome of the agreement will affect and change the Turkish agricultural policy and Common Agricultural Policy of the European Union.

\subsection{Reform Process in Turkish Agricultural Support Policies}

Agricultural support policies date back to 1930s in Turkey. The main policy instruments were market price support, input subsidies, and supply control. Intervention buying of agricultural products started in 1930s with wheat, followed by cotton, tobacco in 1940s. Agricultural Sales Cooperatives and related State Economic Enterprises were commissioned to buy the commodities at floor prices announced by the government. This support was financed by the Agricultural Bank (Ziraat Bankas1). Duty loses of the support system were to be paid by the Treasury according to the Law (Law $3186^{1}$ ) but were always met by the Agricultural Bank (İnan et al., 2003: 20). Support prices were announced after planting, and payments were made one year or more after harvest and delivery; once announced, support prices could not be adjusted for changes in market conditions during the growing season or post harvest (Anderson and Swinnen, 2008: 101).

The commodities supported under Intervention buying were (Acar, 2006: 7980):

1932: wheat and grapes

1938: barley, rye, oat

1940: tea, anise

1941: corn

1944: rice

1947: tobacco

1956: sugarbeet

1966: raisin, fig, cotton, olive oil

1968: nuts, milk

1969: sunflower

1970s: soya bean, lentils, other nut, silk cocoon

The number of supported products increased to 22 in 1970s, started to decline in 1980s and after 1994, only four products were purchased for support: cereals, tobacco, tea and sugarbeet (Çakmak and Kasnakoğlu, 2000: 92). The main objectives of the past agricultural policies were maintaining self-sufficiency, market stabilization and rural development (Screening Chapter, 2006). With the new Agricultural program in 2001, intervention buying was phased out and replaced by Direct Income Support (DIS).

\footnotetext{
${ }^{1}$ In 2000, Law 4572 entered into force.
} 
Input subsidies were the second most important type of agricultural support policy. They were phased out in 2001. The forms of input subsidies were (Çakmak and Kasnakoğlu, 2000: 92):

a. Fertilizer subsidies were started in the 1970s and were fixed in nominal TL per kilogram.

Reduction in the fertilizer subsidy started in 1997 and was completed in 2001 (Burrell and Oskam, 2005:134).

b. $\quad$ Seed subsidies included state-controlled seed production and distribution, subsidies on imported seed purchased by the TMO, and support of hybrid seed producers. They were started in 1985 and ended in 2001.

c. Pesticide subsidies included free protection measures offered by the state in case of epidemic disease or pest infestations. They started in 1985 and were completed in 2001.

d. Cultivation services: Turkish Sugar Factories (TSF) distributed seed beet and paid for the maintenance of machinery and other capital equipment that belongs to the sugarbeet producers.

e. Irrigation subsidies: all water rights, with minor exceptions, were vested in the state. They charged only for the costs of operation and maintenance.

f. Feed subsidies and Improvement of Breeding Stock: these subsidies included animal feed purchase rebates (1985-89) and, industrial feed price support (198889).

The third main support policy was supply control. Supply controls were introduced for three commodities; tobacco (since 1996), hazelnut (since 1983) and tea (since 1987) (Çakmak and Kasnakoğlu, 2000: 92). Supply controls still continue with farmer transition program for hazelnut and tobacco.

In 2000, Turkish Government developed the Agricultural Reform Implementation Project (ARIP) to pursue the aim of the IMF Agreement which was signed in 1999. The project aimed some changes in the support policies like:

1. Reduction of price support and abolition of intervention buying:

The first change was the reduction of price support. With the new Agricultural program, intervention buying (which includes price support) was phased out and replaced by Direct Income Support.

2. Removal of input subsidies:

Input subsidies were the second most important type of agricultural support policy. They were removed in 2001.

3. Restructuring of agricultural sales cooperatives: 
On June 1, 2000, the new Agricultural Sales Cooperative and Agricultural Sales Cooperative Union Law (4572) entered into force. Until then, cooperatives were channels for implementation of government programs. They were responsible for the purchase, storage and also sales on the world market on behalf of the government. With the law, the cooperatives will be independent in terms of management and finance. They will consider their costs and profits in purchases (İnan et al., 2003: 2).

\section{Introduction of Direct Income Support:}

Intervention buying was replaced by direct income support (DIS) payments in 2000. As a pilot program, DIS payments were implemented firstly in Ankara, Antalya, Adiyaman and Trabzon in 2000, and then it was extended to the other regions. According to the support form, the farmers, who are registered to National Farmer Registration System, were eligible to receive a fixed amount of payment up to 50 hectares of cultivated land. Farmers were ineligible for DIS payments for land under 0,01 hectares. Farmers had to be associated with agricultural activity for minimum one production season (8-10 months) on the same land. Agricultural land either needed to be tilled (cultivated to produce crops) or otherwise sustained for agricultural use.

Basic DIS payments were made to the farmers cultivating or sustaining their lands for agricultural use. Additional DIS payments were granted to the farmers who undertake soil analysis, utilize organic farming or certified seed on their land. Basic and additional DIS payments were made on per hectare basis considering the land size of the applicant farmers.

Direct Income Support item of the ARIP was the main discussion point. Direct income support was supposed to compensate the loss of farmers because of the elimination of input subsidies and market price support. But the program was criticised as (Eraktan et al., 2004: 92-97):

- Area based direct payments caused inequality between farm holdings. Large holdings received more payments.

- Land owners receive the payment, but it was not controllable if they used the payment for their private consumes or for farming.

- In Turkey, the inequality of regions was not considered for the amount of direct payments. However, in European Union, less-favoured areas receive more direct payments than the others.

\section{Farmer transition program (for tobacco and hazelnut)}

Farmer Transition helped farmers make the transition to alternative activities. The objective of this component was to cover the cost of converting from previously highly supported crops like hazelnuts and tobacco to alternative products 
(like corn, sunflower, soybean, and lentil). This component provided grants to hazelnut and tobacco farmers to cover the average cost of buying inputs for alternative products and to cover the uprooting costs.

With the policy changes, objective of Turkish agriculture also changed. Objectives of the new support policies were achieving sustainable development, product quality, food security and safety (Screening Chapter, 2006).

\subsection{Current Agricultural Support Policy in Turkey:}

Agricultural Reform Implementation Project ended in 2009, and on 1 June 2009, a new agricultural policy was introduced: "Türkiye Tarım Havzalarının Üretim ve Destekleme Modeli" (basin based support policy). According to this new policy, 30 basins are determined in Turkey, which are ecologically similar. In these basins, the production of 16 commodities (which are supported by deficiency payment) are to be supported by premium payments: barley, safflower, sunflower, wheat, rye, tea, paddy rice, dry bean, canola, lentil, corn, chickpea, cotton, soybean, oat and olives (for oil).

\section{Market access}

Prior to 1980, imports of agricultural products were restricted. Under the import-substitution development strategy, only State Economic Enterprises could import (Kasnakoğlu and Çakmak, 2000: 92). After 1980s Turkey began to open up its economy to world economy and imports were no more restricted. A system of product-specific customs duties was set up that had been introduced in 1980s with a revenue-raising objective. Additional special levies were added (Anderson and Swinnen, 2008: 99): In 1990s, in addition to regular customs duties, agricultural imports were subject to a stamp duty (at $10 \%$ of the value, including cost, insurance and freight (CIF), a wharf tax, (at $5 \%$ of the value, including customs duty and some other charges), the municipality share tax ( a $15 \%$ on customs duty), the DFIF (Destekleme ve Fiyat İstikrar Fonu) levy - price stabilization fund (at 10\% of the value, including CIF). This system was implemented up to 1995. After 1995, Turkey committed itself to comply with the rules of GATT Uruguay Round Agreement. The simple average of applied tariffs in agri-food products are given in Table 1.

Cotton, raw hides and skins are duty free (Table 1). Turkey has high levels of protection in meat, dairy products, sugar and basic cereals. These commodities are considered vital for the survival of the small farmers (Çakmak, 2007: 4). The government also uses "control certificates" issued by the TC Gida, Tarım ve Hayvancılık Bakanlığı to control imported quantities for commodities with low tariffs (Çakmak and Dudu, 2010: 10). 
Table 1: Turkey, Applied Tariffs in Agri-food Products, 2010 (Simple Average)

\begin{tabular}{l|l|l|l|l|l} 
HS & $\%$ & HS & Products & $\%$ \\
\hline 1 & Products & 54 & 16 & Preps of meat, fish, others & 118 \\
2 & Meat and edible meat offal & 138 & 17 & Sugars and sugar confectionary & 114 \\
3 & Fish, crustaceans, molluscs & 29 & 18 & Cocoa and cocoa preps & 67 \\
4 & Dairy, eggs, honey and ed. products & 119 & 19 & Preps.of cereals, flour, starch or milk & 49 \\
5 & Products of animal origin nes & 3 & 20 & Preps of vegs, frutis, nuts etc. & 55 \\
6 & Live trees, cut flowers, etc & 18 & 21 & Miscelaneous edible preps & 12 \\
7 & Ed. vegetables, roots and tubers & 21 & 22 & Beverages, spirits and vinegar & 41 \\
8 & Ed.fruit and nuts, peel of citrus/melon & 44 & 23 & Misc.edib.preps.res.food ind., feed & 9 \\
9 & Cofee, tea, mate, spices & 39 & 24 & Tobacco and manuf.tobacco & 36 \\
10 & Cereals & 52 & $41 \mathrm{p}$ & Raw hides, skins, leather, furskins & 0 \\
11 & Milling industry products & 40 & $50 \mathrm{p}$ & Raw silk, wool, flax & 0 \\
12 & Oilseeds/misc grains/med plants & 17 & $51 \mathrm{p}$ & Wool and hair & 0 \\
13 & Lac, gums, resins, etc & 4 & $52 \mathrm{p}$ & Cotton, not carded or combed & 0 \\
14 & Veg. plaiting mat & 0 & $53 \mathrm{p}$ & Raw flex and hemp & 0 \\
15 & Animal or vegetable fat oils & 22 & & Other WTO-Agricultural Products & 6 \\
& & & & All WTO-Agricultural products & 50 \\
\hline
\end{tabular}

Source: Çakmak and Dudu, 2010: 10

HS: Harmonized System

\section{Export subsidies}

Export levies on high value products (angora wool, dried fruit, nuts) for which Turkey has a large world market share, had been introduced in 1960s with the aim of raising revenue (Anderson and Swinnen, 2008: 99). In recent years, export subsidies have been paid on only 16 products (cut flowers, vegetables frozen (excluding potatoes), vegetables (dehydrated), fruits (frozen), preserves - pastes, honey, homogenized fruit preparations, fruit juices (concentrated), olive oil, prepared or preserved fish, poultry meat, eggs, chocolate and other food preparations containing chocolate, biscuits and waffles, macaroni) with the aim of developing export potential.

\subsection{Reforms in Common Agricultural Policy of European Union}

Common Agricultural Policy (CAP) of the European Union is one of the oldest and the most important policies of the European Union. It is comprised of a set of rules and mechanisms which regulate the production, trade and processing of agricultural products in European Union. It is covered by Articles 32 (Rome Treaty 38 ) to 38 (Rome Treaty 46) of the EC Treaty. The crucial article is the Article 33 (Rome Treaty 39), which sets out the objectives of CAP. The first objective is to increase agricultural productivity by promoting technical progress and by ensuring the rational development of agricultural production and the optimum utilisation of the factors of production, in particular labour. The second is to ensure a fair standard of living for the agricultural community, in particular by increasing the individual earnings of persons engaged in agriculture. The third is to stabilise markets. The fourth objective is to assure the availability of supplies. The final 
objective is to ensure that supplies reach consumers at reasonable prices. In the 1950 s, European Community produced only some $85 \%$ of its own requirements (European Commission, 1992: 26). European Community had to protect and support its agricultural sector in order to ensure production. Common Agricultural Policy led to increase in agricultural production from the 1960s onwards and the European Community became self-sufficient almost in all agricultural products.

From 1962 to 1992 CAP relied on market price support system that had been an important source of distortions and costs. The CAP supported the income of EU farmers through price support policy. A target price was set at high levels which stimulated production. Authorities had to buy the surplus supply of products (to keep the market price close to the target price) when market prices were to fall below intervention prices. Prices at high levels encouraged production and this led to costly storing of food surpluses. To get rid of stocks, export subsidies were required to bridge the gap between lower world prices and higher Community prices. This created a trade problem in the world that many food exporters were harmed because of the disposing of EC's food surplus on the world market at lower prices. $^{2}$ Consumers were also losers of this price system who had to pay more for their products than necessary. The consumption reduction and production increase (due to the high prices) moved the EU towards self-sufficiency in food (Baldwin and Wyplosz, 2009: 356). With this price system, European Community became less dependent on imports. CAP applied high import tariffs so that imports of most price-supported commodities could not be sold into the EU below the desired internal market price set by the EU authorities. In this case consumers would prefer Community's production. Other problem of the CAP price system was that farmers with larger farms benefited more from the support payments (because support was coupled and larger farms produce more) and became richer.

This protectionist agricultural policy occurred problems inside and outside the Community. The need for reform in the CAP became important in the 1980s, because of the high budgetary cost of the $\mathrm{EAGGF}^{3}$ and the imbalance between supply and demand in European markets. The share of CAP in the budget rose from 8\% in 1965 to 80\% in 1969 (Baldwin and Wyplosz, 2009: 361). In 1984 dairy quotas were introduced. Dairy quotas brought spending on dairy sector under

\footnotetext{
${ }^{2}$ EU's food dumping drove down world food prices. A drop in the world prices is a gain for net importers but a loss for net exporters (Baldwin and Wyplosz, 2009: 362).

${ }^{3}$ EAGGF (European Agricultural Guidance and Guarantee Fund) financed the common agricultural policy which was set up in 1962. The fund was replaced by the European Agricultural Guarantee Fund (EAGF) and the European Agricultural Fund for Rural Development (EAFRD) on 1 January 2007 (Council Regulation No 1290/2005 of 21 June 2005). European Agricultural Guarantee Fund (EAGF) finances direct payments to farmers and take measures to regulate agricultural markets such as intervention and export refunds, while the European Agricultural Fund for Rural Development (EAFRD) finances the rural development programmes of the Member States.
} 
control. In 1988, budgetary stabilisers came into effect with the aim of reducing EAGGF guarantee spending.

1992 CAP reform (MacSharry Reform) brought changes in the support system. The reform included the price reduction of the crops (cereals, oilseeds, protein crops) by $29 \%$. The reform changed the way in which subsidies were paid to the farmers, and made radical price cuts. Price support was reduced, and income losses of farmers were compensated with direct payments. Direct payments were paid to big farmers for land set-aside of $15 \%$. Small farmers were exempt from the set aside requirement.

The MacSharry reform of 1992 in Common Agricultural Policy was also prompted by the need to reach agreement in the Uruguay Round (Daugbjerg and Swinbank, 2007: 9). In 1990, the Agriculture Directorate realised that GATT Uruguay Round could not be completed until the CAP was reformed (Daugbjerg, 1999: 418). So the EC took steps to move agricultural policy in a more liberal direction.

Agenda 2000 lowered further price support. Reductions in prices were compensated with direct payments. The Agenda 2000 CAP reform was part of a broader package meant to prepare the European Union (EU) for enlargement, driven by the European Council (Daugbjerg and Swinbank, 2007: 17-18).

Council of Ministers decided in June 2003 on a new CAP reform. Centrepiece of 2003 reform was Single Farm Payment. This payment was independent from production. It was linked to the respect of environmental, food safety, animal and plant health and animal welfare standards (cross compliance). This enabled EU farmers to be more market-orientated and free to produce according to what is most profitable for them (European Commission, 2008: 7). Financial discipline mechanism was agreed in order to ensure that the farm budget was fixed until 2013.

The 2004 reforms concerned "Mediterranean products" and sugar. The reform of agricultural aid for cotton, tobacco, hops and olive oil and table olives was negotiated together and included in the same Regulation (Council Regulation (EC) No 864/2004) known as the "Mediterranean package".

On 20 November 2008 the EU agriculture ministers reached a political agreement on the Health Check of the Common Agricultural Policy (European Commission, 2009):

The agreement abolished arable set-aside, increased milk quotas gradually leading up to their abolition in 2015 and converted market intervention into a genuine safety net. For wheat, intervention purchases are possible during the intervention period at the price of $€ 101,31 /$ tonne up to 3 million tonnes. Decoupled direct aid to farmers (payments) will be no longer linked to the production of a 
specific product. These remaining coupled payments will be decoupled and moved into the Single Payment Scheme (SPS), with the exception of suckler cow, goat and sheep premia. Currently, all farmers receiving more than $€ 5.000$ in direct aid have their payments reduced by 5 percent and the money is transferred into the Rural Development budget. This rate will be increased to 10 percent by 2012 .

On 26 June 2013 a political agreement on the reform of the CAP has been reached between the Commission, the European Parliament and the Council. New tools are suggested, including new market stabilisation instruments, training programmes, local strategies, producer groups, food promotion and improved market and other data/information sources (European Commission, 2013a: 7). New CAP will be more transparent. The main aspects of the reform are presented below (European Commission, 2013b: 1-3):

-Direct payments will be distributed in a fairer way between Member States, between regions and between farmers, putting an end to 'historical references'. Member States will also be able to allocate increased amounts of aid to less-favoured areas.

-Young farmers will be strongly encouraged to set up business.

-Sugar quotas will be abolished by 2017.

-Professional and interprofessional organisations will be promoted, and, for certain sectors, there will be specific regulations on competition law (milk, beef, olive oil, cereals).

-There will be crisis reserve.

-Under rural development programmes, Member States will be able to encourage farmers to take part in risk prevention mechanisms (income support schemes or mutual funds).

-Environmentally-friendly farming practices and rural development programmes will gain more importance to promote sustainability and to help farming meet the challenges of soil and water quality, biodiversity and climate change.

\subsection{Current Agricultural Support Policy in the European Union}

\section{Domestic Support}

Common organisation of agricultural markets regulates the production and marketing of the agricultural products. This organisation governs 21 Common Market Organizations (CMOs). Before 1 July 2008, these CMOs were individual CMOs. They are now under a single CMO. 
Member States receive direct payments which are decoupled in the form of Single Payment Scheme (old member states), Single Area Payment Scheme (new member states). In addition to the single payment, farmers receive coupled aid under other specific support schemes linked to the area under crops or to production (like production aid, premium).

In the Common Agricultural Policy, market intervention includes the reference prices and methods for fixing intervention prices in relation to the reference price, opening periods for buying-in and maximum quantities. Prices are specified for cereals, paddy rice, white and raw sugar, beef and veal, milk, butter, skimmed milk powder and pigmeat.

Private storage aid is specified for certain products (cream and certain butters and cheeses). It is also possible for other products (white sugar, olive oil, fresh or chilled meat from adult bovine animals, skimmed milk powder, cheeses and pigmeat, sheepmeat and goatmeat).

National production quotas are fixed for sugar and milk. Member States then distribute these quotas between the producing undertakings.

\section{Export Refunds}

The export of certain products may be supported by export refunds which cover the difference between global and EU market prices. These may be differentiated according to the destination and are fixed periodically by the Commission, taking account of European Union's and global market developments.

\section{Market Access}

The Commission can require the presentation of import licences for products from certain sectors: cereals, rice, sugar, seed, olive oil and table olives, flax and hemp, bananas, live plants, beef and veal, pigmeat, sheepmeat and goatmeat, poultrymeat, milk and milk products, eggs and agricultural ethyl alcohol. The Commission may also take safeguard measures with regard to imports.

The import duties (specific, advalorem, specific+advalorem), tariff rate quotas, agriculture component (EA) and additional duty (AD) in the Common Customs Tariff apply to the agricultural products. Within the current framework of the Fruit and Vegetables Common Market Organization, EU import measures include: entry price system (EPS) with the import licences system included, special agricultural safeguard clause, tariff rate quotas and sanitary and phytosanitary measures (GEIE Agrosynergie, 2008: 15). Entry Price System (EPS) is to allow imports of fruit and vegetables assuring EU market supply while avoiding that "abnormally" low price 
imports could create "disturbances of Community markets" (Santeramo and Cioffi, 2012: 1$)^{4}$

2. Evaluation of Agricultural Support Policies in the European Union and in Turkey

\subsection{Market Distortion of Agricultural Support in the European Union and in Turkey}

As mentioned before, agricultural support policies are generally protectionist policies. These protectionist policies cause market distortions in the domestic market or world market or both. In figure 1, domestic policies are classified according to the degree of market distortion.

Generally, market distortion arises from price effect and production effect of the domestic policies (Knutson et al., 2007: 104):

1. The price effect results when market prices are artificially raised or lowered relative to the free market.

2. The production effect results when production is artificially raised or lowered relative to the free market.

Figure 1: Domestic Agricultural Policies - ranked by Degree of Market Distortion

High Distortion

No Distortion

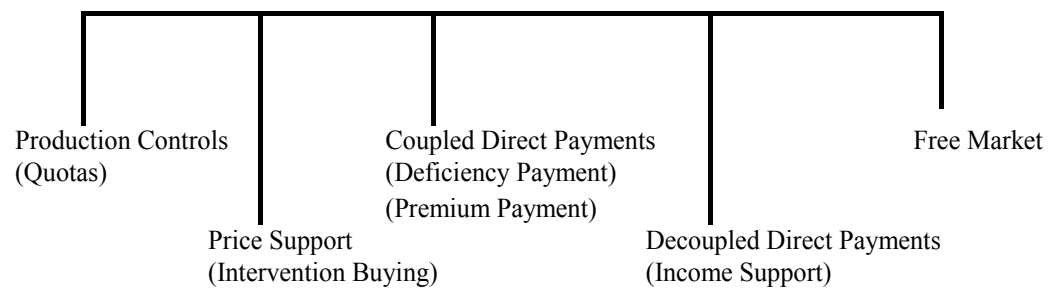

Source: The ranking of domestic agricultural support policies in Turkey are made by using the ranking of domestic agricultural support policies in USA in "Knutson et al., 2007: 105".

In World Trade Organisation (WTO) negotiations, reducing the market distorting domestic policies has been always discussed. WTO separates the agricultural support policies according to the degree of distortion and classifies them in three boxes. The amber (red) box includes the policies with high distortion,

\footnotetext{
${ }^{4}$ Cioffi et al. (2011) analysed the price stabilization effects of the EU entry price scheme for fruit and vegetables. They found that EPS is effective in protecting the EU domestic market of fruits and vegetables from cheap imports (like tomatoes from Morocco and lemons from Turkey), but its effect is not obvious for tomatoes imported from Turkey and lemons imported from Argentina. For furter information see Cioffi et al. (2011) and Santeramo F.G. and Cioffi, A.(2012).
} 
blue box policies are lower distortionary policies and the green box policies are minimally trade distorting.

Table 2 shows the evolution of agricultural support policies in Turkey and in the European Union. The shift from high distortion to low distortion policies (from red box to the green box policies) can be observed from this table.

Table 2: Evolution of Agricultural Support Policies in Turkey and in the EU

\begin{tabular}{|l|c|}
\hline TURKISH AGRICULTURAL POLICY & COMMON AGRICULTURAL POLICY OF THE EU \\
1932: Intervention buying started with wheat & 1962-1992: Market price support \\
1980s: number of supported products was reduced & 1. high budgetary costs of CAP \\
1994: Only 4 products were purchased for support: & 2.Over-production and \\
cereals, tobacco, tea and sugarbeet & costly storing of food surpluses \\
2000: Agricultural Reform Implementation Project & 3.Losers of CAP: Consumers and Third Countries \\
1. Reduction of price support and & 4.Trade-distorting export subsidies \\
$\quad$ abolition of intervention buying & 1984: dairy quotas \\
2. Removal of input subsidies & 1988: budgetary stabilisers \\
3. Restructuring of agricultural & 1992 CAP reform: to limit production, \\
sales cooperatives & to reduce budget costs \\
4. Direct Income Support & price reductions \& compensatory payments \\
5. Farmer transition program & Agenda $2000:$ Single Farm Payment \\
(for tobacco, hazelnut) & Rural development \\
Deficiency payment (16 commodities) & farm budget was fixed until 2013 \\
Quota for sugar & 2008 CAP Health Check: abolition of arable set-aside \\
2009: Basin-based support policy & increase of milk quotas leading up \\
& to their abolition in 2015
\end{tabular}

Source: author (summary of chapter 2)

In Turkey, price support was the most widely used instrument which has a high degree of distortion, because this policy affects both price and production. Price support entails price stabilization and this can be done by lowering the agricultural prices when they are high and by increasing them when they are low (AndressoO'Callaghan, 2003: 67). It is in the amber (red) box. After 2000, deficiency payments were introduced for some selected products. These are coupled payments and may affect the level of production. These payments are blue box policies. To get more deficiency (or premium) payment, farmer may increase the level of production, so the degree of market distortion in coupled payments is higher than the distortion in decoupled payments. Direct income support (a green box policy) was introduced to compensate the loss of farmers occurred because of the elimination of input subsidies and market price support. While these payments are decoupled, it will have no effect on the supply curves for agricultural commodities from domestic producers (Hill, 2012: 131). In 2001 sugar quota was started to be implemented which was the most market distorting policy (red box policy). Production quota affects the production level directly and thus affects the price. By imposing a quota on the maximum amount that farmers are permitted to produce at 
a quantity that corresponds to less than the free-market situation, a new supply curve is created, and by reducing the supply, the market price is raised to the point at which the supply curve intersects the demand curve (Hill, 2012: 136). Production quotas are more distortionary than price supports because, production quotas limit production to a specified level which affect prices. ${ }^{5}$ However, price support changes production quantity to a desired level by using price policy to prevent fluctuations in farmers' incomes.

In the European Union price support was the main instrument in the first years of CAP. As oversupply occurred in the milk sector, milk quotas were introduced in 1984 which was the most trade-distorting instrument. In time owing to the successful CAP reforms, coupled direct payments were replaced by decoupled direct payments that have lower degree of market distortion because they are not tied to production. ${ }^{6}$. European Union had decreased the support level after 1990s and is now moving to a more free market situation. 2013 reform aims to decrease coupled payments and to make CAP more transparent.

\subsection{Level of Agricultural Support in the European Union and in Turkey}

Evolution of support policies can be also analyzed by OECD indicators. OECD indicators are the most widely used indicators to measure support level in agriculture. OECD uses Producer Support Estimate (PSE), Consumer Support Estimates (CSE), General Services Support Estimate (GSSE) and Total Support Estimate (TSE) to measure the level of agricultural support. Producer Support Estimate (PSE) is the annual monetary value of gross transfers ${ }^{7}$ from consumers and taxpayers to agricultural producers, measured at the farm-gate level, arising from policy measures that support agriculture, regardless of their nature, objectives or impacts on farm production or income. If it is negative, the amounts represent an implicit or explicit tax on producers.

\section{Calculation of Producer Support Estimate}

$$
\begin{array}{r}
\text { PSE }=(\text { Market Price support })+(\text { Payments based on output }) \\
=(\text { TPC }+ \text { TPT }+ \text { OTC })+(\text { output support })
\end{array}
$$

$\underline{\mathrm{TPC}}$ : Transfers to producers from consumers $=(\mathrm{DP}-\mathrm{MP}) *$ Production quantity

\footnotetext{
${ }^{5}$ In their study, El-Obeid and Beghin (2006) showed that Turkey expand production when all distortions are removed in the sugar sector. For further information about the removal of agricultural distortions (in the sugar sector), see El-Obeid and Beghin (2006).

${ }^{6}$ A fully decoupled payment is one for which the level of payment is fixed and guaranteed and thus is not influenced by ex-post realizations of market conditions (See Goodwin and Mishra, 2006: 5).

${ }^{7}$ Transfer: Consumers of agricultural commodities and taxpayers represent the two sources of transfers, i.e. the economic groups bearing the cost of agricultural support (OECD, 2008: 18).
} 
DP: border price (import price)

MP: domestic market price)

TPT: Transfers to producers from taxpayers (Production quantity - Consumption quantity)* (DP - MP)

OTC: Other transfers from consumers (Consumption quantity - Production quantity)* (DP - MP)

Market price support and output support are added in the calculation of the producer support estimate. Premium payments, production aid, deficiency payments, subsidies for production are referred as output support. Market price support is denoted as the transfers from consumers and taxpayers to agricultural producers arising from polices that create a gap between domestic market prices and border prices of a commodity. Market price support consists of Transfers to producers from consumers (TPC) which occur when the consumers pay higher prices to the domestically produced commodities due to the market price support; Transfers to producers from taxpayers (TPT) which represent the part of producer price support borne by taxpayers in the form of budgetary outlays on export subsidisation or food aid; and Other transfers from consumers (OTC) which occur when consumers pay the higher price for all consumption, whether the commodity is produced domestically or imported.

Figure 2: Producer Support Estimate in EU, Turkey and OECD

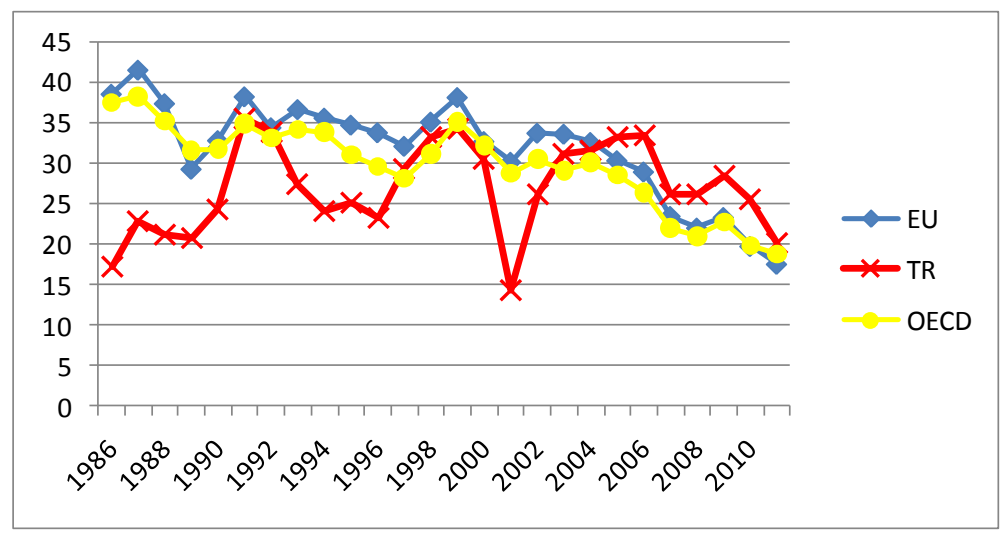

Source: OECD, 2012a.

Figure 2 demonstrates the PSE levels in Turkey, EU and OECD. Agriculture remained one of the most protected areas of international trade. Especially in 1980s high agricultural protection was experienced in all over the world. Uruguay Round negotiations started at the time, when protectionism was high in the world; in 1986, 
producer support estimate in the European Union was recorded as $38,6 \%$ and it was $37,6 \%$ in OECD countries. That means, $38,6 \%$ of the farmer's earnings in the EU come from policy induced transfers, and the remaining come from the value of sales measured at border prices (that is, not including price support). On the contrary, 1980s were the years of trade liberalization in Turkish agriculture. In fact, Turkey did not support its agriculture heavily as experienced in the developed countries. Turkey had protected agriculture by border measures like high tariffs. So, PSE level was not so high in Turkey and it was around $17 \%$ in 1986. At the end of 1980 s, the PSE level of Turkey increased gradually and converged to the EU and OECD levels. 1991 was the year of highest protection in the world as seen in the figure. Gürkan and Kasnakoğlu (1991) denoted that political and economic events affect the support and protection levels in agricultural products. In Turkey, prior to the election and soon after it, agricultural support increased, and reached its highest level in 1991 when the general election was held. Since 1994, due to increased frequency in elections and internal political activity, high levels of support have been maintained (Çakmak, 2003: 3).

GATT Uruguay Round Agreement on Agriculture (URAA) resulted in support level reductions in the EU. Besides URAA, 1992 MacSharry Reform also contributed to the process of reductions in support level. The European Union benefited greatly from the agreement to use a 1986 baseline for reductions in market access (1986-88 baseline), domestic support 1986-88 baseline) and export subsidies (1986-90) because the baseline years were recorded as the highest protection years. It provided extra protection margin in all areas. So, although EU carried out its Uruguay Round commitments, the support levels remained high even at the end of the implication period of the commitments despite the reductions in market access, export subsidy and domestic support commitments (OECD, 2012a): The PSE (Producer support Estimate) was 35\% in 1995 and $34 \%$ in 2002. The PSE average of the OECD countries was $31 \%$ in 1995 and $31 \%$ in 2002 (1986-88 average was $37 \%$ ).

On the contrary, Turkey's support level was not as high as the OECD countries' PSE. Turkey had already reduced its protection level before the Uruguay Round in market access aspect: in 1980s, Turkey had reduced the tariffs in agricultural products during the liberalization process. For this reason, Turkey did not need to adjust its tariffs because of its WTO commitments. In the case of export subsidies; Turkey had bound export subsidies for 44 products/product groups but Turkey was below the bound limits for most products and close to the limit (quantity or budget) for a few products only. Regarding the domestic support, Turkey had de minimis support for all products. This means that domestic product specific support policies were not to exceed 10 percent of the production value of the product concerned. After Uruguay Round, Turkey's PSE level remained high except 2001. The 2001 
financial crisis caused the sharpest decline in the agricultural support. The shift from market price support (intervention buying) to premium payments appeared in a downward trend. After recovering the crisis, PSE level started to increase until 2006. From 2007 onwards, the PSE trend in Turkey has followed the OECD and EU level. In the last years, owing to the changes in the support policies, the PSE level started to decrease and declined to $20 \%$ in 2011 which was the lowest level since 1986 (except the crisis year 2001). European Union also lessened its support level after 2003 due to the successful CAP reforms. The EU farming became more market oriented and environment friendly.

Tables below summarize the composition of producer support estimate in Turkey and in the European Union.

Table 3: Composition of Producer Support Estimate (Turkey)

\begin{tabular}{|l|r|r|r|r|r|r|r|r|}
\hline Support / Year & 2001 & 2005 & 2006 & 2007 & 2008 & 2009 & 2010 & 2011 \\
\hline PSE - EUR mln & 2.900 & 13.309 & 13.817 & 11.916 & 12.301 & 12.255 & 15.664 & 11.220 \\
\hline $\begin{array}{l}\text { Support based on } \\
\text { output (\%) }\end{array}$ & 76,4 & 86,8 & 83,8 & 79,6 & 82,4 & 89,9 & 90,2 & 88,4 \\
\hline $\begin{array}{l}\text { Payments based } \\
\text { on input use (\%) }\end{array}$ & 3,4 & 2,4 & 5,1 & 6,3 & 5,5 & 3,5 & 2,0 & 3,0 \\
\hline $\begin{array}{l}\text { A. Other } \\
\text { payments (\%) }\end{array}$ & 19,8 & 10,6 & 10,8 & 7,7 & 4,9 & 0,0 & 0,0 & 0,0 \\
\hline
\end{tabular}

Source: OECD 2012b.

Notes:

A. Other payments: Payments based on non-current on current area planted/animal numbers/revenues/incomes, production not required (like direct income support (DIS), grubbing-up hazelnut payment)

B. Other payments: Payments based on current on current area planted/animal numbers/revenues/incomes, production required (include: sugar compensation, potatoes compensation payments, tea pruning payments, tobacco compensation payments, Agricultural insurance - crops and livestock, transition payments, genetic resources payment, cattle breed registration payment, feed crops premium, diesel payment, fertilizer payment, land conservation)

Changes in agricultural support policies are reflected in table 3. Main support policy in Turkey consists of support based on commodity output which is a coupled direct payment. In 2001, the PSE accounted for $€ 2.900$ million, $87 \%$ of which was output support. Second most important support type comprises of payments (B) that requires production. Input subsidies make up of approximately $3 \%$ of payments. PSE was higher in 2010 and 2011 it was $€ 11.220$ million.

Table 4 shows the composition of producer support estimate in the European Union. Producer support estimate in the European Union has a decreasing trend. In 
2011, PSE declined to $€ 74.203$ million from $€ 99.425$ million in 2005 (table 4). The main support element had been output support. In time, thanks to the successful CAP reforms, share of the output support lessened and decoupled payments came into question. While output support was $51 \%$ in 2001, it decreased to $13 \%$ in 2011 . Payments that do not require production became important. Moreover, almost 50\% of the support payments include payments based on non-current area planted/animal numbers/revenues/incomes, production not required. Input payments also increased in the last years.

Table 4: Composition of Producer Support Estimate (European Union)

\begin{tabular}{|l|r|r|r|r|r|r|r|r|}
\hline Support / Year & 2001 & 2005 & 2006 & 2007 & 2008 & 2009 & 2010 & 2011 \\
\hline PSE - EUR mn & 89.793 & 99.425 & 98.719 & 90.827 & 90.197 & 85.649 & 77.317 & 74.203 \\
\hline $\begin{array}{l}\text { Support based on } \\
\text { output (\%) }\end{array}$ & 51,6 & 49,0 & 39,1 & 34,2 & 29,0 & 26,3 & 16,7 & 12,9 \\
\hline $\begin{array}{l}\text { Payments based } \\
\text { on input use (\%) }\end{array}$ & 8,4 & 10,0 & 11,0 & 12,3 & 12,4 & 12,8 & 15,0 & 15,2 \\
\hline $\begin{array}{l}\text { A. Other payments } \\
(\%)\end{array}$ & 0,0 & 16,2 & 31,0 & 35,2 & 37,2 & 40,0 & 47,7 & 50,9 \\
\hline $\begin{array}{l}\text { B. Other payments } \\
(\%)\end{array}$ & 38,9 & 23,9 & 17,3 & 16,3 & 17,8 & 18,4 & 17,9 & 18,7 \\
\hline $\begin{array}{l}\text { C. Other payments } \\
(\%)\end{array}$ & 0,0 & 0,1 & 0,2 & 0,2 & 0,2 & 0,2 & 0,2 & 0,1 \\
\hline $\begin{array}{l}\text { Payments based } \\
\text { on non-commodity } \\
\text { criteria }\end{array}$ & 1,3 & 1,4 & 1,8 & 1,9 & 3,4 & 2,0 & 2,3 & 2,0 \\
\hline $\begin{array}{l}\text { Miscellaneous } \\
\text { payments }\end{array}$ & $-0,1$ & $-0,5$ & $-0,3$ & $-0,1$ & 0,0 & 0,3 & 0,1 & 0,1 \\
\hline
\end{tabular}

Source: OECD, $2012 b$.

Note: C. Other payments: Payments based on non-current area planted/animal numbers/revenues/incomes, production required

\section{Conclusion}

Agriculture is a sensitive issue in every country, so each country applies agricultural support policies. Since the World War II, European countries attached importance to food security and self-sufficiency. The objectives in the founding Treaty let the Community apply protectionist policies. Whenever the problems of support emerge, EU has not made necessary structural reforms. Instead EU has adhered to make temporary adjustments in CAP. So level of agricultural support has not decreased to desired level. After the Uruguay Round and MacSharry Reform in 1990s, the Community started to shift CAP from price supports to direct income supplements. However, after EU fulfilled its URAA commitments, it was 
criticised of being highly protectionist in agriculture. Using the 1986-90 baseline in the commitments provide EU to obey the WTO rules, while at the same time protecting its agriculture. The reforms after EU enlargement make the EU to give importance to structural issues like environment, food safety, animal welfare more than distributional policies such as financial support like input payments, output payments. In time, due to the reforms, producer support estimate has fallen to desired levels. The share of output support and input support decreased and payments that do not require production came to the fore. The European Union shifted CAP from protectionist policy to a less-trade distorting policy. Nevertheless, EU still supports the farmers, but the way money spent is differently. The reforms broke the link with support and payments, but income support continues under the name "cross compliance". Although farmers receive money transfers from their agricultural applications, producer support estimate is at low levels. When we look at Turkey's implementations, we see that agricultural support policies were applied in the opposite direction of CAP. 1980s were protectionist years in the EU, while they were liberalization years in Turkey. When the CAP started to move away from the protectionist policies, Turkey began to support its agriculture through output and input support in 2000s. The share of the output support had been always high in the last ten years in Turkey. The link between payments and production are not broken. Instead, payments that do not require production were abolished, input support and premium payments gained importance. While the support volume has not been high as experienced in the EU, producer support estimate levels are not also high despite output payments. They have been converging to the EU and OECD levels.

To sum up, European Union and Turkey developed their agricultural support policies differently and tried to change the way of support in time with the help of the reforms and GATT Uruguay Round Agreement on Agriculture. The ongoing Doha Round negotiations are also expected to alter the support policies in the member countries. European Union and Turkey proposed their preferences in the Round. Whatever their positions would be no matter, the outcome of the negotiations is expected to decrease further support level in Turkey and in the European Union, and to reduce the dependence of payments on output. 


\section{References:}

Acar, M., (2006), DTÖ ve AB Işı̆̆ııda Türk Tarımının Geleceği. Ankara: Orion Yayınevi.

Anderson, K. \& Swinnen, J., (2008), Distortions to Agricultural Incentives in Europe's Transition Economies. Washington: World Bank.

Andreasso-O'Callaghan, B., (2003), The Economics of European Agriculture. New York: Palgrave Macmillan.

Baldwin, R. \& Wyplosz, C., (2009), The Economics of European Integration. United Kingdom: The McGraw Hill Companies, Third Edition.

Burrell, A. M., \& Arie J. O., (2005), Turkey in the European Union: implications for agriculture, food and structural policy. United Kingdom: CABI Publishing.

Cioffi, A., Santeramo, F.G. and Vitale, C.D., (2011), The price stabilization effects of the EU entry price scheme for fruit and vegetables. Agricultural Economics, 42 (3), pp. 405-418.

Çakmak, E. H. \& Kasnakoğlu, H. (2000). Turkey, Valdes, A. (2000), Agricultural Support Policies in Transition Economies. Washington: World Bank Technical Paper No: 470.

Çakmak, E. H., (2003), "Evaluation of the Past and Future Agricultural Policies in Turkey: Are They able to Achieve Sustainability?", Options Méditerranéennes, A (52), pp. 155 165.

Çakmak, E. H., (2007), "Trade Liberalisation and Turkish Agriculture: Threat or Opportunity", Barcelona: Cal-Med Workshop III.

Çakmak, E. H. \& Dudu, H., (2010), Agricultural Support Policy Reform Program of Turkey: Lessons Learned and Assessment. OECD background paper. Ankara.

Daugbjerg, C., (1999), Reforming the CAP: Policy Networks and Broader Institutional Structures. Journal of Common Market Studies, 37 (3), pp. 407-428.

Daugbjerg, C. \& Swinbank, A., (2007), “The Politics of CAP Reform: Trade Negotiations, Institutional Settings and Blame Avoidance", Journal of Common Market Studies, 45 (1),pp. 1-22.

El-Obeid, A. \& Beghin, J., (2006), "Multilateral Trade and Agricultural Policy Reforms in Sugar Markets", Journal of Agricultural Economics, 57, pp. 23-48.

Eraktan, G., Abay, C., Miran, B., \& Olhan, E., (2004), Türkiye'de Tarımın Teşvikinde Doğrudan Gelir Desteği Sistemi ve Sonuçları. İstanbul: İstanbul Ticaret Odası Yayın No: 2004-53.

Ertuğrul, C., (2004), Tarımda Küreselleşme, Uruguay Görüşmeleri ve Sonrası. Ankara: Odak Yayınevi.

European Commission (1992), Agriculture in Europe; Development, Constraints and Perspectives. Luxemburg.

European Commission (2008), The Common Agricultural Policy Explained. Brussels.

European Commission (2009), "Health Check" of the Common Agricultural Policy. Brussels.

European Commission (2013a), The Common Agricultural Policy after 2013; Public debate. Brussels. 
European Commission (2013b), Political agreement on new direction for common agricultural policy. Brussels.

GEIE (Groupement Européen d'Intérêt Economique) Agrosynergie (2008), Evaluation of the system of entry prices and export refunds in the fruit and vegetables sector. Italy (study financed by the European Commission).

Goodwin, B. K. \& Mishra, A. K., (2006), “Are 'decoupled' farm program payments really decoupled? An empirical evaluation”, American Journal of Agricultural Economics, 88 (1), pp. 73-89.

Gürkan, A. A. \& Kasnakoğlu, H., (1991), "The political economics of agricultural price support in Turkey: An empirical assessment”, Public Choice 70 (3), pp. 277-298.

Hill, B., (2012), Understanding the Common Agricultural policy. London: Earthscan.

İnan, H., Gaytancıŏlu, O., Erbay, R. \& Yılmaz, F., (2003), Gelişmiş Ülkelerde Tarım Piyasalarının Organizasyonu. İstanbul: İstanbul Ticaret Odası Yayın No: 2003-53.

Knutson, R., Penn, JB., Flinchbaugh, B. \& Outlaw, J., (2007), Agricultural and Food Policy. Ohio: Pearson Prentice Hall, Sixth Edition.

OECD (2009). The PSE Manual. Retrieved: March, 29 2010, from http://www.oecd.org/tad/agricultural-policies/psemanual.htm.

OECD (2012). 2012 Producer Support Estimate by country. Retrieved: April 15, 2013, from http://stats.oecd.org/Index.aspx?DataSetCode=MON20123_1.

OECD (2012). OECD Countries: Composition of Producer Support Estimate by country. Retrieved April 15, 2013, from http://stats.oecd.org/Index.aspx?DataSetCode=MON20123_1.

Santeramo F.G. \& Cioffi, A., (2012), "The entry price threshold in EU agriculture: Deterrent or barrier?", Journal of Policy Modeling, vol. 34(5), pp. 691-704.

Screening Chapter 11: Agriculture and Rural Development (23 - 26 January 2006). Agenda Item 1: Turkish Agricultural Policy. Avrupa Birliği Genel Sekreterliği (ABGS). Ankara.

Yılmaz, Ö., (2012), “Agricultural Support Policies for Olive Oil, Wheat, Milk, Sugar in Turkey with Reference to CAP”, unpublished Ph.D. thesis, İstanbul: Marmara University. 